\title{
YOUTH ENTREPRENEURIAL DEVELOPMENT: A PANACEA FOR OVERCOMING SECURITY CHALLENGES AND UNEMPLOYMENT IN NIGERIA
}

\author{
Elizabeth Uzoamaka Okechukwu \\ Enugu State University of Science and Technology, Enugu \\ $\&$ \\ Mabel Ngozi Nwekwo \\ University of Nigeria, Enugu Campus
}

\begin{abstract}
Nigeria has a large youth population that often plays a key role in the conflict, most especially violent ones. Youth unemployment in Nigeria constitutes a security challenge and can endanger socio-economic development. This paper examines youths' entrepreneurial development as a panacea for overcoming security challenges and unemployment in Nigeria. The study was carried out using the survey design. Both primary and secondary data were utilized for the study. The descriptive statistics of simple percentages, frequencies, tables, means, and standard deviation were employed to analyze the data, while inferential statistics of z-test was used to test the hypotheses. The findings of this study revealed that causes of security challenges in Nigeria are unemployment, lack of good governance, corrupt practices of government officials, lack of quality education, lack of basic infrastructure facilities, poverty and marginalization of the youth. The researchers recommended that entrepreneurial education through training and skill acquisition could be a means through which the government may curtail security and unemployment situation in Nigeria. The most effective way for these youth to become catalysts for change and economic growth is through entrepreneurship. This research implies that no meaningful development would be achieved without first dealing with unemployment situation in Nigeria.
\end{abstract}

Keywords: Challenges, development, entrepreneurship, security, unemployment, youth

\section{Introduction}

The quality of life, scope and scale of the future greatness of a nation is always determined by the quality of investment in the condition of its youth (Gaskia, 2014). A nation that trivializes the current condition of its youth is merely laying the foundation for the decline and irrelevance of the nation in the global community of the future and without highly educated, highly literate, highly skilled, intellectually brilliant and self-confident youth, a nation is toying with its future, and undermining its existential capacity for economic stability.

Security challenges and unemployment has been on the increase in almost all communities in Nigeria. Since the inception of transition from military to the civilian regime, there has been a mass proliferation of unravelled violence, killing of innocent people; and, most recently, the bomb blasts, kidnapping and abduction (Yusuf, 2014).

The progress of a nation depends on the level of the resourcefulness of the citizens which to a great extent, relates to the level of quality of the training and skill acquisition in that nation.

Such progress or development could only occur when individuals in the society are gainfully employed. This could only be achievable when government entrepreneurial policies are geared toward training and skill acquisition; which in turn can accelerate economic development and 
employment generation that can lead to self-reliance and crime reduction. Production of skilful and quality entrepreneurs in achieving the Millennium Development Goals (MDGs) in Nigeria remains a mirage if youth restiveness is not tackled.

Okoye-Nebo, Iloanya and Udunze (2014) opine that the development and transformation of Nigerian and the Sub-Sahara Africa are highly dependent on youth empowerment through entrepreneurship. The youths are the engine for economic development and play important role in curtaining security challenges. Major causes of social vices such as fraud, kidnapping, armed robbery, destitution, prostitution, terrorism, political thuggery and so on can be attributed to unemployment.

Nigeria with the labour force of approximately 3 million people annually moving into the labour market, unemployment of persons of 15 years and above was put at $3.8 \%$ and youth unemployment estimated at 5.0\%, as at 2006 (Osibanjo, 2006 in Okoye-Nebo, et al (2014)). Instability and conflict in less developed countries have been linked with expanding youth populations, particularly among youth who have had limited economic opportunities (Ali, 2014). The resulting instability and conflict from youth unemployment poses significant barriers to meaningful and sustainable development and negatively impacts economic activity.

\section{Statement of the problem}

In Nigeria, there has been a prevalence crime, such as the killing of innocent people, robbery, kidnapping, politically motivated assassination, abduction, bomb blasts and most recently Fulani herdsmen. Security threats in Nigeria are concern with such dehumanizing conditions as violent conflicts, the proliferation of arms and small weapons, endless streams of refugees and internally displaced people, force labour, exponential violence against women, abject poverty, corruption, the lack of basic health care, terrorism, and the rape of constitutionalism and the rule of law.

The security challenges of the Nigerian state are that democracy is most likely to be undermined, thereby paving way for a military incursion in the country. The incessant internal insurrection by armed youths across the country could be a problem for any efforts by the government to achieve economic development in Nigeria.

The phenomenon of youth involvement in conflict is deeply rooted in a crisis of governance that has ensnared them; which has manifested in many forms. It could result over the distribution of wealth, power-sharing, the inability of the government to provide and protect its citizens, arbitrary and solitary exercise of power, and the collapse of economic and social structures and institutions. These issues stand to expose youths toward violence and crime.

Nevertheless, when the basic issues of increase in youth unemployment and disenfranchisement are not addressed properly, cities around the world will continue to face a toxic cycle of instability, insecurity, crime, poverty, and unemployment that will undermine socio-economic development. With the foregoing, it is against this background that this paper examines youths' entrepreneurial development as a panacea for overcoming security challenges and unemployment in Nigeria. 


\section{Objectives of the Study}

The main objective of the study was to examine youths' entrepreneurial development as a panacea for overcoming security challenges and unemployment in Nigeria; while the specific objectives are:

1. To determine the effect of security challenges on economic development in Enugu State.

2. To ascertain how much positive effect entrepreneurship development has on youth employment generation.

3. To examine the relationship between entrepreneurship development and crime reduction in Enugu state.

\section{Hypotheses}

The following three null hypotheses were postulated to guide the study.

$\mathrm{H}_{1}$ : There is no positive relationship between security challenges and economic development in Enugu state.

$\mathrm{H}_{2}$ : Entrepreneurship development has no positive relationship with youths' employment generation in Enugu state.

$\mathrm{H}_{3}$ : There is no positive relationship between entrepreneurship development and crime reduction in Enugu state.

\section{Literature review}

The term youth has been variously defined and given different interpretations by organizations, countries and cultural groups across the globe. In the 2009 second national youth policy document of the Federal Republic of Nigeria persons between the ages of 18-35 years, who are citizens of Nigeria, have been defined as youths.

Nigeria's population is said to have reached about 167 million people in 2012 (National Bureau of Statistics, 2012). The National Population Commission (2013) states that about half of the population is made up of youth, defined as individuals between 15 and 35 years of age. Unfortunately, as the youth population grows, so does the unemployment rate. Also National Bureau of Statistics in its 2012 national youth survey report; disclosed that youths of working age, in the age bracket of 15 to 35 years are nearly 70 million persons in a population of 166 million Nigerians; of these youths $54 \%$ are unemployed.

Unemployment exists when members of the labour force who wishes to work but cannot get jobs (Adebayo, 1999). Youth unemployment, therefore, could be described as the conglomerate of youths with a diverse background, willing and able to work, but cannot find any; or cannot find the type of job that they are trained to do, and which they will be proud to do as their area of expertise (Uddin and Uddin 2013).

Youths are central to the development agenda of a nation and safeguarding their rights and investing in their future means providing quality education, decent employment, effective livelihood skills, access to sexual reproductive health and comprehensive sexuality education are essential to their development and country at large. 
Youth occupy a prominent place in any society. Apart from being the owners and leaders of tomorrow, they outnumber the middle-aged and the aged (Onyekpe, 2007). Besides numerical superiority, youth have energy and ideas that are society's great potentials (Onyekpe, 2007). The National Youth Development Policy (2001:1) asserts that:

Youth are the foundation of society. Their energies, inventiveness, character and orientation define the pace of development and security of a nation. Through their creative talents and labour-power, a nation makes giant strides in economic development and socio-political attainments. In their dreams and hopes, a nation founds her motivation; on their energies, she builds her vitality and purpose. And because of their dreams and aspirations, the future of a nation is assured.

The above statement acknowledges the role of the youth in the peace and security of a nation. As the most active segment of any society, youth are the major determiners of peace and stability of a nation (Ozohu-Sulaiman, 2006). Conversely, the degree of disorderliness and instability in society is also determined by youth participation. Without peace, there is no development. The absence of peace means that no meaningful development can take place. Youths all over the world are a vital and important segment of the society in which we live. Disciplined focused and law-abiding youth can create a bright future for any nation. Conversely, a lawless, indulgent, and violent youth is a great threat to a nation's peace and security (Anasi, 2010).

\section{Causes of youth crime in Nigeria}

Elegbeleye (2005) identifies three major factors: the peer motivated excitement of being a youth, the jingoistic pursuit of patriotic ideals, and perceived victimization arising from economic exploitation.

Ofem and Ajayi (2008) on the study on the Niger Delta region identified lack of humanitarian and social welfare, lack of good governance, corrupt practices of government officials, inadequate training programmes, unemployment, inadequate recreational facilities, lack of quality education, and a host of others, as the reasons for incessant youth restiveness.

Several closely-related factors are responsible for youth restiveness in Nigeria.

(i) Bad Governance: Good governance is required for the growth and development of any nation. Unfortunately, in Nigeria, bad governance has resulted in disjointed development. Onyekpe (2007) observes that successive administrations in Nigeria have not allocated much to the needs of the youth, and, worse still, the meagre allocation are often diverted by government officials to their private accounts and projects. Thus, youths are restive and agitated when they perceive that resources meant for them are being wasted by those in authority or governance.

(ii) Unemployment: Ozohu-Suleiman (2006) notes that Nigerian youth are trapped by unemployment. Zakaria (2006) believes that "the rising tide of unemployment and the fear of a bleak future among the youth in African countries have made them vulnerable to the manipulations of agents' provocateurs." These include aggrieved politicians, religious demagogues, and greedy multinationals that employ these youths to achieve their selfish ambitions. Zakaria (2006) strongly believes that the absence of job opportunities in developing countries is responsible for youth restiveness with disastrous consequences. Developing 
countries like Nigeria face the biggest burden in the youth unemployment crisis. Often characterized by weak economies, inequality, and poverty, these countries are unable to create enough jobs for the exploding youth population (ILO, 2014).

(iii) Poverty: Poverty is a condition in which people lack basic satisfactory material resources (food, shelter, clothing, housing), are unable to access basic services (which includes health, education, water, sanitation), and are constrained in their ability to exercise rights, share power and lend their voices to the institutions and processes which affect the social, economic and political environments in which they live and work. ILO (2003) asserts that poverty is a "vicious circle of poor health, reduced working capacity, low productivity and shortened life expectancy." Aworawo (2000) and Zakaria (2006) agree that there is a link among poverty, loss of livelihood, inequality, and youth restiveness as evidenced by the numerous violent protests against the wielders of power in Nigeria.

(iv) Inadequate Educational Opportunities and Resources: Quality education has a direct bearing on national prestige, greatness, and cohesion (Nedeljkovic, 2014). The knowledge and skill that young people acquire help determine their degree of patriotism and contribution to national integration and progress. Between 2000 and 2004, about 30 per cent of Nigerian youth between 10 and 24 were not enrolled in secondary school (Population Reference Bureau, 2006). Perhaps the prohibitive cost of acquiring education is responsible. The aftereffect of this situation is that thousands of young people roam the streets in cities in Nigeria unemployed. Those who manage to complete secondary school have no opportunities for tertiary education. Having being denied the chance to reach their potential, they are disorientated and readily available for antisocial actions (Onyekpe, 2007).

(v) Lack of Basic Infrastructure facilities: Most rural communities and urban slums in Nigeria have no access to potable water, health facilities, electricity, communication facilities, industries and commercial facilities, accessible roads, etc. The major causes of social unrest and youth restiveness in the country are the agitation for the equitable distribution of resources. Nedeljkovic, (2014) opines that communication creates room for sharing information. It helps people express their thoughts and feelings, clarify problems, and consider alternative ways of coping or adapting to their situation. Such sharing promotes social cohesion. Youths need to have access to communication facilities, to communicate with the policymakers making the decisions that affect them. Sadly, rarely do youths in Nigeria participate in decision-making processes on issues that affect their lives. Ifidon and Ahiauzu (2005), in their study of Niger Delta, revealed that inadequate communication and information flow is one factor responsible for youth restiveness in the area.

(vi) Marginalization of the Youth: There is an increasing number of youth living in cities in Nigeria that are facing daunting economic and social challenges, including social exclusion, lack of economic opportunities, and limited access to resources (Uzochukwu, 2016). They are increasingly marginalized, excluded from the economic growth of cities, and forced to live on the margins of society. Globally, increase rapid urbanization and the social and economic exclusion of youth have had serious social ramifications. Un-engaged and disaffected youths who lack the economic opportunities to raise themselves out of poverty and illiteracy are more vulnerable than adults to engage in armed violence, kidnapping, crime, gangs, drug trafficking, and other secret activities (Ali, 2014). Increasingly, rapid urban growth without a corresponding increase in job opportunities for youth increases the risk of political and social turbulence.

\section{Causes of youth unemployment in Nigeria}

Akande (2014) assert that several factors may be blamed for the prevalence of youth unemployment in Nigeria. 
(1) High population growth rate of 3.5 per cent per annum which is accompanied by an already large national population of over 167 million people;

(2) Deficient school curricula and poor teacher training have contributed to the failure of educational institutions to provide their students with the appropriate skills to make them employable.

(3) Deficient in infrastructure, teaching facilities and teacher quality;

(4) Mass failure in national examinations conducted among final-year secondary school students, which made many of them unemployable.

(5) Lack of vibrant industries to absorb competent graduates which was caused by infrastructural deficit that led to the closure of many industries;

(6) Flawed and inconsistent public policies on employment;

(7) Policymakers have not confronted the problems of inadequate information and data that can form the basis of effective planning.

Uddin and Uddin (2013) enumerated causes of unemployment as follows:

(a) Rural-urban migration: Youths move to urban areas with the probability of securing lucrative employment in the industries. In addition to this, there is a concentration of social amenities in the urban centres. This meant that rural areas are neglected in the allocation of social and economic opportunities.

(b) Rapid population growth: Going by the 2006 census in Nigeria, the nation's population was put at 140,431,790 and projections for the future indicate that the population could be over 180 million by the year 2020, given the annual growth rate of 3.2 per cent (National Population Commission and ICF Macro, 2009). It is argued that the high population growth rate has resulted in the rapid growth of the labour force, which is far outstripping the supply of jobs. The accelerated growth of population on Nigeria's unemployment problem is multifaceted. It affects the supply side through a high and rapid increase in the labour force relative to the absorptive capacity of the economy.

(c) The low standard of education: most of the Nigerian graduates are not employable and, does not possess the required skills by the employers of labour for formal employment. This may be attributed to Nigeria's education system. The course contents of most tertiary education in Nigeria lack entrepreneurial contents that would have enabled graduates to become job creators rather than job seekers.

(d) The rapid expansion of the educational system: The rapid expansion of the educational system which directly leads to increase in the supply of educated manpower above the corresponding demand for them, contributes to the problem of the youth unemployment in Nigeria. The reality is that the Nigerian economy is too weak to absorb this large number of graduates (Utomi, 2011).

(e) Lack of steady and sustainable power supply: The fact is that Nigeria is becoming hostile to investment due especially to lack of steady and sustainable power supply/energy crises leading to firms depending on generators for their operation whose cost of buying, fuelling and maintenance is high, thereby increasing the cost of operation (Adeloye, 2010). When the industries and factories closed shops or relocated to a friendlier economic 
environment, workers were laid off and the prospect of recruiting new ones was dashed. All these exacerbated the crisis of youth unemployment in the labour market (Onifade, 2011).

(f) Corruption: Funds marked for developmental projects have been misappropriated, diverted, or embezzled and stashed away in foreign banks, while some incompetent and corrupt bureaucrats and administrators in the public enterprise and parastatals have liquidated these organizations (Okafor, 2011). Thus, crippling the economy and engendering and exacerbating unemployment which creates abject poverty, hunger, frustration, crime and insecurity.

(g) Lack of skills: One of the principal causes of unemployment among youths in different nations of the world is the lack of requisite skills which can increase their self-employment. In Nigeria, undergraduates are most often interested in acquiring material certificates without attention to skill acquisition. It is shameful to hear that those who graduated from electronics and computer engineering in most developing or underdeveloped countries cannot produce or repair any electrical appliance. The major reason for that is because the skills needed are lacking.

(h) Bad governance: The World Bank (1992) identifies the main characteristics of bad governance to include, failure to properly distinguish what is public and what is private, leading to private appropriation of otherwise public resources; arbitrariness in the application of law and rules and excessive rules, regulations, licensing requirement and so forth which impede the functioning of markets and encourage rent-seeking. Other forms of bad governance are priorities that are inconsistent with development, thereby resulting in a misallocation of national resources, and exceedingly narrow base or non-transparent decision making (Chiepaka, 2012).

(i) Poor mechanization: Mechanization can be defined as the introduction of machines or automation to facilitate production processes. In Nigeria, many people are still making use of crude equipment for cultivation of crops. This results in many quitting or find it difficult to become engage in agriculture as their source of employment. Many establishments would have employed more and more workers if there are good mechanization processes that are obtainable in those establishments.

\section{Consequences of youth unemployment}

When youths are unemployed they are readily available for anti-social criminal activities that undermine the stability of society. An unstable society increases the risk of the market. This scares investors. If the youths are unemployed and underemployed they are more vulnerable to conflicts and illegal activities (European Youth Forum, 2011).

Unemployment among youths could lead to unhappiness and mental health problems. Not having a job can cause economic, cultural and social isolation. Youth unemployment is associated with an increase in drug and alcohol use as well as higher levels of crime among young people (Nedeljkovic, 2014).

High youth unemployment hurts economic growth and productivity. There is a risk of loss of talent and skills since a great number of university graduates are unable to find a job and to put their knowledge and capabilities into producing innovation and contributing to economic growth. Moreover, having a large share of the young workforce unemployed, not only leads to reduced productivity and gross domestic product (GDP) but also increases the economic costs for the state, since there is more money to be paid on social benefits and less money coming in from taxes (European Youth Forum, 2013). 
The large number of youths who are unemployed is capable of undermining democratic practice as they constitute a serious threat if engaged by the political class for clandestine activities (Abioye, 2011). In Nigeria, there has been a prevalence crime, such as the killing of innocent people, robbery, kidnapping, rape, politically motivated assassination, abduction, bomb blasts and most recently Fulani herdsmen.

\section{Entrepreneurship and youth employment}

Entrepreneurship is the ability and willingness of individuals to develop, organize and manage a business enterprise along with associated risks to make a profit. Henry (2003) views entrepreneurship as the engine driving the economy of nations, creating new industries, young entrepreneurs, employments and wealth. Agbionu (2008) opines that entrepreneurship involves a process aimed at creating wealth for growth, development of the environment and eradication of unemployment for national sustainability.

Entrepreneurship is the acquisition of skills and ideas for the sake of creating employment for oneself and also, for others. It also includes development based on creativity. Entrepreneurship leads to the development of small, medium and sometimes, large scale business based on creativity and innovation. The success of the business in turn helps in developing the nation. It also reduces the poverty rate with a visible increment of employment rate among the youths.

Anyadike, Emeh and Ukah (2012) argue that entrepreneurship is more than simply "starting a business." It is a process through which individuals identify opportunities, allocate resources, and create value. This creation of value is often through the identification of unmet needs or the identification of opportunities for change. Entrepreneurial success is simply a function of the ability of an entrepreneur to see opportunities in the marketplace, initiate change (or take advantage of change) and creates value through solutions.

Entrepreneurship gives youths a sense of ownership and participation in economic activity and leverages their immense potential and the economic potential of the cities they live in. The most effective way for these youths to become catalysts for change and economic growth is through entrepreneurship. There are benefits to promoting entrepreneurship among youths beyond the creation of economic opportunities for the unemployed. From a social perspective, entrepreneurship addresses some of the socio-psychological problems and criminal activity that result from unemployment. Entrepreneurship also re-integrates marginalized and disaffected youths into the economic mainstream of their cities; youths who were previously forced into the margins of society gain a sense of meaning, self-worth, and belonging.

Continuous lack of employment opportunities for the youth, particularly in urban cities in Nigeria, is among the greatest security and development challenges today and has resulted in the underemployment, inequality, marginalization of youth, crime and violence among youths.

It is therefore essential to develop strategies to harness the incredible power of youth inventiveness and dynamism to generate economic growth and employment. Rather than being a burden, the bulge can become a demographic gift. Entrepreneurship and the private sector can leverage the potential of this population and provide a bottom-up approach to youth job creation. 
The role of entrepreneurship in employment generation

The following are basic economic importance of entrepreneurship in generating employment and reduction in crime (Ibrahim, 2010):

a. Wealth creation: Rural entrepreneurship enables individuals to use their potentials and energies to create wealth for themselves in the society.

b. Poverty reduction/eradication: generation of employment will therefore reduce the level of poverty.

c. Rural-urban migration: Rural entrepreneurial activity in generating employment is the link achieving this balance.

d. Reduction of crime rate: When individual are unable to satisfy their needs, most often, frustration occurs. These frustrations breed fraudulent practices such as armed robbery, political thuggery, ritual killing, hot men or hired assassination, drugs peddling, prostitution, advance fee fraud (aka "419"), money laundering, currency counterfeiting, oil bunkering, e-mail scam, mercenaries, war-mongering and other such related crimes among others. Employment generation will reduce the level of frustration and crime rate.

e. Raise the standard of living: entrepreneurship through job and wealth creation raises the standard of living among youths. Owing to higher-income earning and availability of disposable income, they can, therefore, afford to acquire the necessities of life such as housing, clothing and food, education, good health care delivery, etc.

f. Economic development: Enterprises through employment generation stimulate development and the achievement of a meaningful level of broad economic development.

g. Encourages capital formation: When individuals are employed, they can afford to save out of their disposable income. Entrepreneurs can, therefore, facilitate the use of these untapped savings thereby stimulating capital formation/accumulation, which is the engine of economic growth.

h. Skills acquisition and an increase in general productivity level: employment can be a training ground where an individual discovers or acquires and develops skills for creativity leading to a general increase in productivity level.

\section{Entrepreneurship development in youth}

Many different initiatives exist to promote youth entrepreneurship, from providing training to youths who want to start their own business to venture capital funds helping to promote these businesses.

(a) Promoting entrepreneurial spirit among youth: It is, therefore, essential to create an entrepreneurial ecosystem which promotes a thriving entrepreneurial culture that can drive innovation and employment. There are three essential elements to creating this ecosystem: strengthening educational systems with a focus on entrepreneurship training, developing a supportive and enabling environment which makes it easier to launch a business, and financing businesses owned and operated by youth.

(b) Skill acquisition: Youth can be a positive force for development when provided with the knowledge and opportunities they need to thrive. In particular, young people should acquire the education and skills needed to contribute in a productive economy, and they need access to a job market that can absorb them into its labour force (United Nations, 2015).

(c) Access to credit: Access to credit and capital alone is far from sufficient to leverage the opportunities of youth-owned businesses. Youth entrepreneurs must develop the skills to run modern, sustainable businesses that can compete and grow in a competitive environment. Formal training in such areas as business plan development, management, financial 
management, and opportunity identification and capitalization provide the foundation for launching and growing successful enterprises. Education programs also need to focus on transferable and marketable entrepreneurial skills that can be directed toward the creation of new and small businesses that leverage the benefits of the urban economy.

(d) Enabling Environment: It also essential to create an enabling environment with rules, policies, and regulations that make it easier for youth to launch businesses. These policies should include implementing legislation to encourage young entrepreneurs to become involved in social and economic development and increasing the ease of doing business through easier business registration and set-up processes. This will encourage investors to invest and thereby create jobs to absorb the unemployed youths.

(e) There should also be a policy on youth education and development through the provision of scholarship and empowering them technically by providing them with employment facilities.

\section{Methodology}

The study adopted a survey approach using a sample of 384 respondents derived from a large and infinite population from both rural and urban dwellers using Cochran (1963) formula adopting a quota sampling technique. 316 copies of questionnaire representing $82 \%$ of the questionnaire were accepted for analysis. The study used three local government areas, each selected from the three geographical zones in Enugu state comprising Enugu East (AbakpaNike), Enugu West (Udi) and Enugu North (Udenu).

Primary and secondary sources of data were the main data used for the study. The scale adopted for the measurement was five-point Likert scale, with answers ranging from 1 to 5, or strongly agree to strongly disagree. The data were analyzed using both descriptive and inferential statistics. Pearson correlation was used to reflect the degree of the linear relationship between two variables and determines the strength of the linear relationship between the variables.

\section{Data Analysis}

Table 1: Causes of youth crime in Nigeria

\begin{tabular}{|l|l|l|l|l|l|l|l|l|}
\hline Options & $\begin{array}{l}\text { SA } \\
(\mathbf{5})\end{array}$ & $\begin{array}{l}\mathbf{A} \\
\mathbf{( 4 )}\end{array}$ & $\begin{array}{l}\mathbf{U D} \\
\mathbf{( 3 )}\end{array}$ & $\begin{array}{l}\text { SD } \\
(\mathbf{2})\end{array}$ & $\begin{array}{l}\mathbf{D} \\
(\mathbf{1})\end{array}$ & $\mathbf{N}$ & $\overline{\mathbf{X}}$ & Remarks \\
\hline Bad Governance & 298 & 49 & 0 & 0 & 0 & 310 & 5 & Accepted \\
\hline Unemployment & 176 & 48 & 0 & 92 & 0 & 310 & 4 & Accepted \\
\hline Poverty & 148 & 110 & 5 & 32 & 21 & 310 & 4 & Accepted \\
\hline $\begin{array}{l}\text { Inadequate educational } \\
\text { opportunities and } \\
\text { resources }\end{array}$ & 105 & 116 & 0 & 10 & 0 & 310 & 3.6 & Accepted \\
\hline $\begin{array}{l}\text { Lack of basic } \\
\text { infrastructure facilities }\end{array}$ & 269 & 21 & 0 & 0 & 20 & 310 & 4.6 & Accepted \\
\hline $\begin{array}{l}\text { Marginalization of the } \\
\text { youth }\end{array}$ & 94 & 116 & 0 & 111 & 0 & 310 & 3.6 & Accepted \\
\hline Lack of skill/training & 290 & 50 & 0 & 0 & 0 & 310 & 5 & Accepted \\
\hline $\begin{array}{l}\text { Peer motivated excitement } \\
\text { of being a Youth }\end{array}$ & 20 & 18 & 13 & 211 & 48 & 310 & 2.2 & Rejected \\
\hline
\end{tabular}

Source: Field Survey 2019 
In table 1, mean responses from 3.00 and above were accepted as causes of youth crime in Nigeria; while the mean response below 3 was rejected.

Table 2: Ways to promote youth entrepreneurship development

\begin{tabular}{|l|l|l|l|l|l|l|l|l|}
\hline Options & $\begin{array}{l}\text { SA } \\
(\mathbf{5})\end{array}$ & $\begin{array}{l}\mathbf{A} \\
\mathbf{( 4 )}\end{array}$ & $\begin{array}{l}\text { UD } \\
\mathbf{( 3 )}\end{array}$ & $\begin{array}{l}\text { SD } \\
(\mathbf{2})\end{array}$ & $\begin{array}{l}\mathbf{D} \\
(\mathbf{1})\end{array}$ & $\mathbf{N}$ & $\overline{\mathbf{X}}$ & Remarks \\
\hline $\begin{array}{l}\text { Promoting entrepreneurial } \\
\text { spirit among youth }\end{array}$ & 298 & 49 & 0 & 0 & 0 & 310 & 5 & Accepted \\
\hline Skill acquisition & 176 & 48 & 0 & 92 & 0 & 310 & 4 & Accepted \\
\hline Access to credit & 148 & 110 & 5 & 32 & 21 & 310 & 4 & Accepted \\
\hline Enabling Environment & 105 & 116 & 0 & 10 & 0 & 310 & 3.6 & Accepted \\
\hline Provision of Infrastructure & 269 & 21 & 0 & 0 & 20 & 310 & 4.6 & Accepted \\
\hline Formal education & 94 & 116 & 0 & 111 & 0 & 310 & 3.6 & Accepted \\
\hline
\end{tabular}

\section{Source: Field Survey 2019}

From table 2, mean responses from 3.00 and above were accepted as ways to promote youth entrepreneurship development.

Table 3: $\quad$ Role of entrepreneurship in employment generation

\begin{tabular}{|l|l|l|l|l|l|l|l|l|}
\hline Options & SA & A & UD & SD & $\mathbf{D}$ & $\mathbf{N}$ & - & Remarks \\
\hline Wealth Creation & $\mathbf{( 5 )}$ & $\mathbf{( 4 )}$ & $\mathbf{( 3 )}$ & $\mathbf{( 2 )}$ & $\mathbf{( 1 )}$ & & $\mathbf{X}$ & \\
\hline Poverty Reduction/Eradication & & & & & & & & \\
\hline $\begin{array}{l}\text { Reduction in Rural-Urban } \\
\text { Migration }\end{array}$ & 291 & 49 & 0 & 0 & 0 & 310 & 5 & Accepted \\
\hline Reduction of Crime Rate & 265 & 29 & 0 & 0 & 20 & 310 & 4.6 & Accepted \\
\hline Raise Standard of Living & 115 & 106 & 0 & 10 & 0 & 310 & 3.6 & Accepted \\
\hline Economic Development & 142 & 110 & 5 & 32 & 21 & 310 & 4 & Accepted \\
\hline Encourages Capital Formation: & 173 & 45 & 0 & 92 & 0 & 310 & 4 & Accepted \\
\hline $\begin{array}{l}\text { Skills acquisition and increase } \\
\text { in general productivity level }\end{array}$ & 298 & 12 & 0 & 0 & 0 & 310 & 5 & Accepted \\
\hline Eradication of crime & 21 & 17 & 13 & 213 & 46 & 310 & 2.2 & Rejected \\
\hline
\end{tabular}

Source: Field Survey 2019

In Table 3 above, mean responses from 3.00 and above were accepted as the role of entrepreneurship development in employment generation; while mean response below 3 were rejected. 
Table 4: Relationship exist between youth entrepreneurial development and security challenges, unemployment and crime

\begin{tabular}{|c|c|c|c|c|c|c|c|c|c|c|}
\hline \multirow[t]{2}{*}{$\mathbf{S} / \mathbf{n}$} & \multirow[t]{2}{*}{ Questions } & \multicolumn{5}{|c|}{ Responses } & \multirow{2}{*}{ 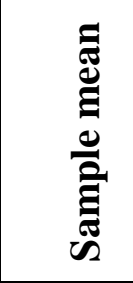 } & \multirow{2}{*}{\multicolumn{2}{|c|}{ 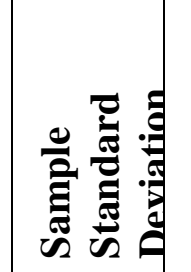 }} & \multirow{2}{*}{ 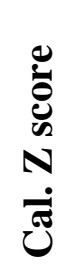 } \\
\hline & & $\begin{array}{c}\text { SA } \\
5\end{array}$ & $\begin{array}{l}A \\
4\end{array}$ & $\begin{array}{l}\mathrm{U} \\
\mathbf{3}\end{array}$ & $\begin{array}{l}\mathrm{D} \\
\mathbf{2}\end{array}$ & \begin{tabular}{|c} 
SD \\
$\mathbf{1}$
\end{tabular} & & & & \\
\hline 1. & $\begin{array}{l}\text { Security challenges has no14t } \\
\text { positive relationship with } \\
\text { entrepreneurial development }\end{array}$ & 8131 & 32 & 20 & & 21 & 3.15 & 15.2 & & \\
\hline 2. & $\begin{array}{l}\text { Unemployment has no } \\
\text { positive relationship with } \\
\text { entrepreneurial development }\end{array}$ & 122 & & 124 & 30 & 21 & 134 & 03.53 & 18.5 & \\
\hline 3. & $\begin{array}{l}\text { Crime has no positive } \\
\text { relationship with } \\
\text { entrepreneurial development1 }\end{array}$ & 28517 & & & 5 & .313 .5 & 9922.43 & & & \\
\hline
\end{tabular}

\section{Source: Questionnaire distributed 2019}

Table 4 ascertains the relationship between youths' entrepreneurial development with security challenges, unemployment and crime. In respect to the relationship between security challenges, unemployment and crime with entrepreneurial development; their responses are strongly agree, agree, undecided, disagree, and strongly disagree with frequencies of 146, 81, 31,32 and 20 out of 310 respectively giving a sample mean of 4.21, sample standard deviation of 3.15 and calculated $\mathrm{z}$ score of 15.2 greater than the table $\mathrm{z}$ score of 1.64 . The analysis indicated that most of the respondents either strongly agreed or agreed with the question at a $5 \%$ level of significance.

From Table 4 the respondents were asked to indicate whether unemployment has a relationship with entrepreneurial development. Their responses are strongly agree, agree, undecided, disagree, and strongly disagree with frequencies of 122, 124, 30, 21 and 13 out of 310 respectively giving a sample mean of 4.30, sample standard deviation of 3.53 and calculated $z$ score of 18.53 greater than the table $\mathrm{z}$ score of 1.64. This showed that most of the respondents either strongly agreed or agreed that Unemployment has no positive relationship with entrepreneurial development.

On the relationship between crime and entrepreneurial development; the responses were strongly agree, agree, undecided, disagree and strongly disagree with frequencies of 172,85 , 17,11 , and 25 out of 310 respectively giving a sample mean of 4.31 and a sample standard deviation of 3.59 and a calculated $\mathrm{z}$ score of 22.43 greater than the table $\mathrm{z}$ score of 1.64 . Therefore, majority of the respondents agreed that crime has no positive relationship with entrepreneurial development 
Table 5: Correlation analysis of relationship between youth entrepreneurial development with security challenges, unemployment and crime

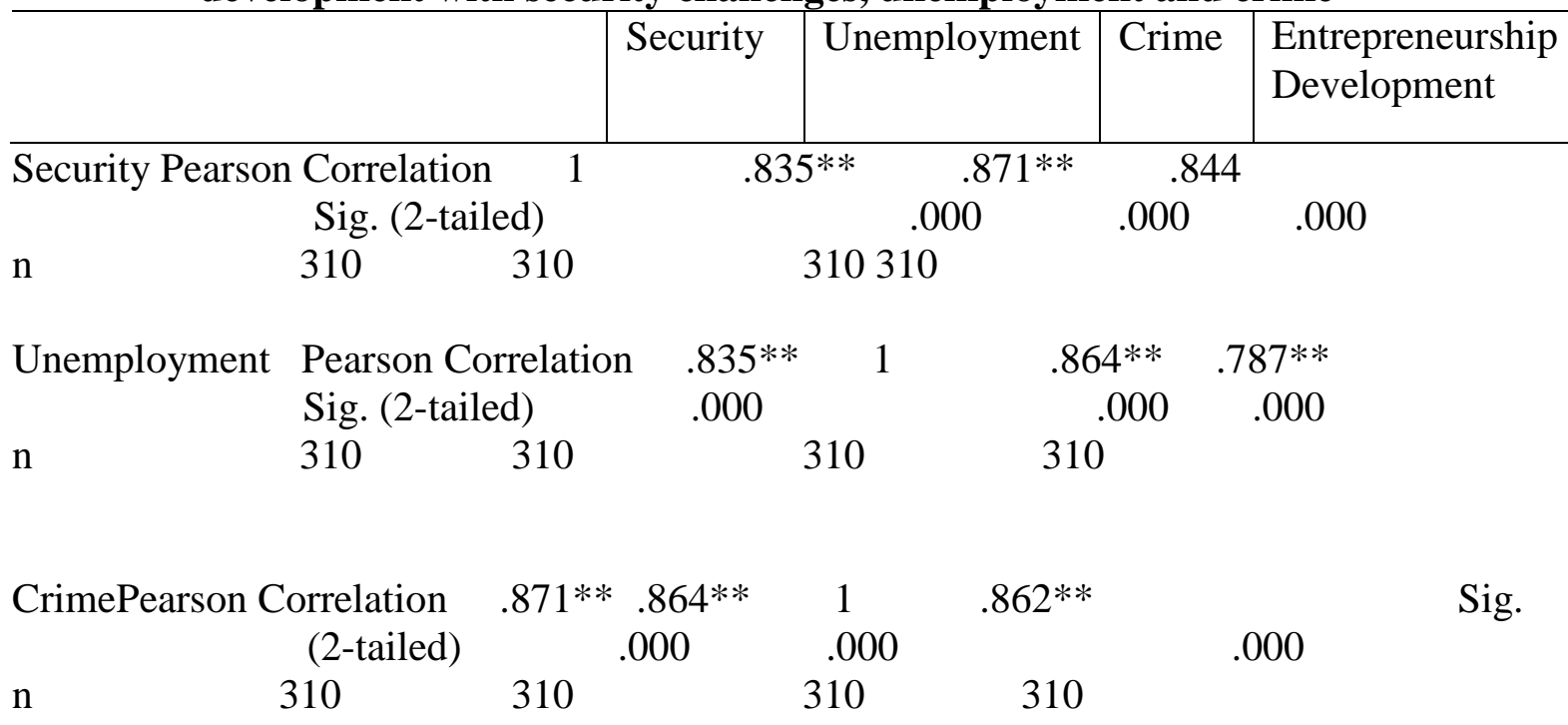

Entrepreneurship Pearson Correlation.844**.787**.862** 1

Development Sig. (2-tailed)

** Correlation is significant at the 0.05 level (2-tailed).

Table 5 examines the correlation analysis of youth entrepreneurial development traits to entrepreneurship development. The value for security is 0.844 which shows the high significance of relations; while values for unemployment and crime are 0.787 and 0.862 respectively. Since all the values of youth-entrepreneurial development traits have no significant relationship with entrepreneurship development. Therefore, the three null hypotheses were accepted.

Table: 6: ANOVA

\begin{tabular}{|l|l|l|l|l|l|}
\hline Model & Sum of Squares & df & $\begin{array}{l}\text { Mean } \\
\text { Square }\end{array}$ & F & Sig. \\
\hline \multicolumn{1}{|l|}{ Regression } & 5629.247 & 4 & 1284.315 & 17.254 & $.000 \mathrm{a}$ \\
& 1726.665 & 306 & .515 & & \\
Residual & 7355.912 & 310 & & & \\
\hline
\end{tabular}

a. Predictors: (Constant), Security challenges, unemployment and crime

b. Dependent Variable: Entrepreneurship development

From the analysis in table $3, \mathrm{~F}=17.254$ showing that the predictors or independent factors, namely security challenges, unemployment and crime, combine to predict entrepreneurship development in Enugu State. The value of significance lies between $0 \%$ and 5\%, showing that the model is a good fit. Reading from table 6 , the value of significance is 0.000 , showing that 
all the predictor variables combine to predict the entrepreneurship development in Enugu State. Since the relationship between independent and dependent variables is highly significant, we opine that the model is a good fit.

\section{Summary of findings}

1. The study revealed that there is no positive relationship between security challenges and economic development in Enugu state. Security challenges affect entrepreneurship and economic development.

2. It was found out that entrepreneurship development has a positive relationship with youths' employment generation in Enugu state. Youth can be a positive force for development when provided with the knowledge and opportunities they needed to thrive.

3. The study indicated that there is no positive relationship between entrepreneurship development and crime reduction in Enugu state. Employment generation will reduce the level of frustration and crime rate. Employment can be a training ground where an individual discovers or acquires and develops skills for creativity leading to a general increase in productivity level.

\section{Conclusion}

Increases in youths' unemployment in Nigeria pose a security problem; which can endanger the peaceful co-existence of the country. There will be no meaningful and sustainable development in the economy where there are insecurity and an increase in crime.

\section{Recommendations}

1. Empowering youth through education, skill acquisition to become entrepreneurs is the best means of achieving economic development, unemployment and crime reduction.

2. The Federal Government of Nigeria should create enabling socio-economic and political environment including provision of infrastructure to make industrial climate investment conducive and friendly.

3. Education curriculum at all levels should be revised to incorporate skills acquisition and entrepreneurship development.

\section{References}

Abioye, U. (2011). Spinning off an Entrepreneur Culture among Nigerian University Students: Prospects and Challenges, African Journal of Business Management, 3(3), 80-88.

Adebayo, A. (1999). Youth Unemployment and National Directorate of Employment Self Employment Programmes, Nigerian Journal of Economics and Social Studies, 41(1), 81102.

Adeloye, L. (2010). Harsh Operating Environment Claims 834 Nigerian Manufacturing Companies-Investigation, Sunday Punch, 4,21.

Agbionu, T. U. (2008). The Basics of Business Success: An Entrepreneurship Practical Approach, Lagos: Topline Publishers. 
Akande, T. (2014). Youth Unemployment in Nigeria: A Situation Analysis retrieved from https://www.brookings.edu/blog/africa-in-focus/2014/09/23/youth-unemployment-innigeria-a-situation-analysis/

Ali, M. (2014). Youth Unemployment: A Global Security Challenge retrieved from http://hir.harvard.edu/youth-unemployment-a-global-security-challenge/

Anasi, S.N.I (2010). Curbing Youth Restiveness in Nigeria: The Role of Information and Libraries retrieved from http://www.webpages.uidaho.edu/ mbolin/anasi.htm

Aworawo, D. (2000). Mal-distribution and Poverty as Factor in the Crisis of the Nigerian State in the constitution, Journal of Constitutional Development, 1(12), 1-13.

Chiepaka, I.J. (2012).Towards Curbing Youth Restiveness retrieved from http://www.thetidenewsonline.com/2012/08/20/towards-curbing-youth-restiveness/

Elegbeleye, O.S. (2005). Recreational Facilities in Schools: A Panacea for Youths' Restiveness, Journal of Human Ecology, 18(2), 93-98.

European Youth Forum (2011). Youth Unemployment in Europe: A Call for Change, Brussels, European Youth Forum retrieved from http://issuu.com/yomag/docs/a_call_for_change

European Youth Forum (2013). Policy Paper on Youth Unemployment, Adopted by the Council of Members on 19-20 April 2013, Brussels, COMEM/GA 0166-13-FINAL retrieved from $\quad \mathrm{http} / / \mathrm{www} . y 0 u t h f o r u m . o r g / a s s e t s / 2013 / 08 / 0166-$ 13_PP_Employment_Final.pdf

Gaskia, J. (2014). The Condition of Youth in Nigeria and the Urgent Imperative for Political action retrieved from http://saharareporters.com/2014/08/12/condition-youth-nigeria-andurgent-imperative-political-action-jaye-gaskiaetriev.

Henry, F. I. (2003). Entrepreneurship Development in Third World: A Realistic Approach, New York: Graw Hill Inc.

Ibrahim, H. (2010). The Role of Rural Entrepreneurship in Employment Generation, Journal of Arts and Contemporary Society, 5(9), 78-89.

Ifidon, S.E. and Ahiauzu, B. (2005). Information and Conflict Prevention in the Niger Delta Region of Nigeria, African Journal of Libraries, Archives, and Information Science, 15(2), 125-132.

International Labour Organization (2003). Youth: Pathway to Decent Work-(Defining Youth), Geneva: International Labour Office.

International Labour Organization (2014). Global Employment Trends, Geneva: International Labour Office.

National Bureau of Statistics (2009). Social Statistics in Nigeria, Abuja: The NBS Publication. 
National Bureau of Statistics (2012). Statistical News: Labour Force Statistics No. 476, Abuja: The NBS National Population Commission and ICF.

National Population Statistics and ICF Macro (2009). Nigeria Demographic and Health Survey, 2008, Abuja: Nigeria.

National Bureau of Statistics (2010). Statistical News: Labour Force Statistics No. 478.Abuja: The NBS Publication.

Nedeljkovic, V. (2014). Consequences of High Youth Unemployment retrieved from http://www.bridgingeurope.net/consequences-of-high-youth-unemployment.htm.

Ofem, N.I., \& Ajayi, A.R. (2008). Effects of youth empowerment strategies on conflict resolutions in the Niger Delta of Nigeria: Evidence from Cross River State, Journal of Agriculture and Rural Development 6 (12), 139-146.

Okafor, E.E. (2011). Youth Unemployment and Implications for Stability of Democracy in Nigeria retrieved fromhttp://www.jsdafrica.com/Jsda/V13No1_Spring2011_A/PDF/Youth\%20Unemploy ment $\% 20$ and $\% 20$ Implications $\% 20$ For $\% 20$ Stability\%20of\%20Democracy\%20(Okafor).p df

Okoye-Nebo, C. Iloanya, K. and Udunze, U. (2014). Youth Unemployment and Entrepreneurship Development: Challenges and Prospects In Nigeria, Kuwait Chapter of Arabian Journal of Business and Management Review, 4(4),20-3.

Onifade, D. (2011). Power Supply: We need the Facts. The Guardian, 8(4), 23.

Onyekpe, N. (2007). Managing Youth at Election, A Journal of Constitutional Development, 7 (1),76-87.

Osibanjo, O. (2006). Concept of Entrepreneurship: A Paper Presented at the workshop on Entrepreneurship and Innovation for 200 -Level students in University of Ibadan, Jan. 18.

Ozohu-Suleiman, A. (2006). The Nigerian Youth in Contemporary Political Development: Relevance, Challenges, and Role Expectation, Journal of Constitutional Development, 6(4), 97-111.

Population Reference Bureau (2006). The World's youth 2006 datasheet retrieved from http://www.prb.org/pdf06/WorldsYouth2006Data Sheet.pdf

Uddin, P. S. O. and Uddin, O. O. (2013). Causes, Effects and Solutions to Youth Unemployment Problems in Nigeria, Journal of Emerging Trends in Economics and Management Sciences, 4(4), 397-402.

United Nations (2015). Assessment of Youths Employment in Rivers, Delta, Kaduna, Kano \& Plateau States of Nigeria, Financial Report, 5,17.

Utomi, P. (2011). Betraying the Mission of the Generation, The Guardian,12 (5), 12. 
Uzochukwu, M. (2016).Unemployment: Causes and Consequences retrieved from http://hubpages.com/money/unemployment-causes-and-consequences

World Bank (1992). Governance and Development, Washington, DC: International Bank for Reconstruction and Development. 